\title{
Globalization and Modernity in Marx and Postone
}

\begin{abstract}
In this article, I intend to show that a categorical analysis of the Marxian concept of wealth may prove useful for understanding the contradictory effects of globalization. Authors like Douglas Kellner point out that globalization is a dual process, containing both positive and negative aspects. Moishe Postone has developed an immanent critique of capitalism that contrasts the forms of domination in modern society with its emancipatory potential. I intend to pursue Postone's categorical reading, addressing in particular the concept of wealth. I will try to show that social wealth involves the possibility of a multilateral social form, based on the universal spread of knowledge, and freed from the 'unilateral' form of production in capitalism.
\end{abstract}

\section{Introduction: critical theory of modernity and globalization}

Douglas Kellner calls for a 'critical theory of globalization' capable of understanding its positive or negative aspects. He rejects optimistic visions, such as that of Francis Fukuyama, who ignores negative aspects of globalization such us wars, poverty and economic crises. On the other hand, unilateral Marxist interpretations are equally reductionist, since they only analyze globalization in terms of the imposition of capitalism. These views ignore the possibilities for radical politics and alternative forms of globalization, embodied in a 'globalization from below' (Kellner 2002, p. 286). A critical theory of globalization should prove capable of understanding both its oppressive logics and liberating possibilities.

I propose that Moishe Postone's categorical reading of Karl Marx's mature work can provide the foundations for a critical theory of globalization. Capitalist modernity as such can be interpreted as a form of domination (constituted by the fetishistic mediation of labor) and as the source of emancipatory potentials (since the alienated dynamic of value creates the possibility of its eventual overcoming). The contradiction between wealth and value can give an account of the

Facundo Nahuel Martín, Universidad de Buenos Aires (UBA) / Centro de Investigaciones Filosóficas (CIF)

Ә OpenAccess. (C) 2018 Facundo Nahuel Martín, published by De Gruyter. (cc) BY-NC-ND This work is licensed under the Creative Commons Attribution-NonCommercial-NoDerivatives 4.0 License. 
dialectic between domination and emancipation in global society. Capitalism is based on a specific form of social domination, which is not based on personal authority but on impersonal, abstract and quasi-objective compulsions. Capitalism contradictorily creates the possibility of what I will call 'social wealth'. This possibility aims towards a different form of production and social mediationone that would no longer be based on the reproduction of value as a fetishistic compulsion imposed on individuals. Globalization, from this perspective, is both the universalization of capitalist domination (based on the mediation of society by the value form) and the ground for liberating possibilities.

\section{Postone's categorial reading of Marx}

In Time, labor and social domination, Postone presents a reformulation of critical theory grounded in the contradictory forms of social mediation under capitalism. Labor as a specifically capitalist social form produces an alienated social universal, opposed to the individuals as an independent power. Capitalist social mediation possesses an impersonal and objective nature: "[s]ociety, as the quasi-independent, abstract, universal Other that stands opposed to the individuals" (Postone 1993, p. 159). Capitalism configures an oppressive society by its characteristic 'form of labor', which generates alienated forms of social mediation.

Capitalist social relations mediated by labor compose a historically specific totality governed by value and labor as self-mediating principles. Totality involves the lack of freedom of its subjects, but also entails the inherent possibility of its transformation. "The categories of the adequate critique, as I have argued, must grasp not only the contradictory character of the totality but also the basis of the sort of unfreedom that characterizes it” (Postone 1993, p. 125).

Labor as a social mediating principle imposes an alienated goal for human activity that must be attained, disregarding the concrete needs of the subjects. "Labor is separated from its concrete purpose and becomes a means toward a goal given by the alienated structures constituted by (abstract) labor itself" (Postone 1993, p. 325). Value-producing labor posits itself as a compulsive social goal that disregards any other particular needs or purposes, constituting a selfmediating totality.

Capital's global dynamic is self-contradictory as well. It both undermines the basis of its own development and creates the foundations for its possible overcoming. Capital possesses a dynamic of transformation and restitution of the labor hour. It constantly increases the productivity of labor. Thus, the social labor hour becomes increasingly 'dense' in terms of the amount of commodities produced. This is the 'concrete' aspect of the capitalist temporal process. Yet, the 
transformations in production do not lead to an increase in value; or rather, they only bring about temporary increases (extraordinary surplus value). Value depends ultimately on the labor time employed, not on its productivity: "although increased productivity does result in more material wealth, it does not result in more value per unit of time" (Postone 1993, p. 195). The 'abstract' aspect of the capitalist temporal dynamic (empty, homogeneous time) is therefore restored after every concrete transformation of the social labor hour. Once a productive level is socially generalized, the magnitude of value created during the labor hour remains stagnant, regardless of the amount of material wealth it represents.

Capitalism's temporal dynamic leads to a growing discrepancy between wealth and value. If capital must constantly increase the productivity of labor, it also restores value, each time, as a uniform and abstract measure:

This process of the reciprocal determination of the two dimensions of social labor in capitalism occurs on the level of society as a whole. It is at the heart of a dialectical dynamic intrinsic to the social totality constituted by commodity-determined labor. (Postone 1993, p. 289)

The dialectic of transformation and restitution of the social labor hour also inherently makes capitalism increasingly anachronistic. As technical developments grow, 'direct' labor becomes ever less relevant in production. Instead, the socially general powers of science and technique become the leading factors of production. "[Capitalism] renders the production of material wealth essentially independent of direct human labor time expenditure” (Postone 1993, p. 339). The generation of material wealth and that of value enter into contradiction. This opens up the possibility for the overcoming of capitalism.

In the following sections, I will attempt to show how the contradiction between wealth and value can shed light on some emancipatory potentials of globalization. In order to do this, I will attempt a categorical analysis of the concept of wealth in Marx's Grundrisse. Wealth should not be defined only by the creation of greater masses of goods, but by the social determinations under which those goods are produced and consumed.

\section{Unilateral social forms and wealth}

I aim to show that Marx, in his Grundrisse manuscripts, provides a historically determinate concept of social wealth. Marx, I will claim, regards both capitalism and pre-capitalist societies as unilateral. The former is one-sided because it is based on production for the reified goal of value. The latter appear as unilateral 
because they are based on determined forms of tradition and authority. The idea of social wealth, as a multilateral development of human needs and capacities, confronts both. Let us first consider Marx's account of what social wealth could mean:

\begin{abstract}
But in fact, when its narrow [bornierte] bourgeois form is eliminated, what is wealth but the universality of needs, capacities, enjoyments, etc. of individuals, generated by the universal exchange? The full development of human mastery over the forces of nature, both the socalled nature and their inner nature? The absolute elaboration of their creative assets, without any other presupposition than the previous historical development, which makes this totality of development, that is the development of all human forces as such, not measured by a previous standard, an end in itself. Where it dos not reproduce itself in a determinateness [Bestimmtheit], but produces its totality. [Where] it does not seek to remain as anything that has become [Gewordnes], but in the absolute movement of its becoming. In the bourgeois economy-and the production era that corresponds to it-this complete elaboration of the human interior appears as complete emptying; this universal objectification [Vergegenständlichung] as total alienation [Entfremdung]; and the destruction of all determinate unilateral ends [bestimmten einseitigen Zwecke] as the sacrifice of the end in itself [Selbstzwecks] under a completely external end. Therefore, on the one hand the childish old world appears as the higher. On the other hand it is so in everything where closed shape, form and given limitation is sought. It is satisfying from a narrow [bornierte] point of view; while the Modern remains unsatisfying or, where it appears satisfied in itself, it is vulgar [gemein]. (Marx 1983, p. 411) ${ }^{1}$
\end{abstract}

Marx uses the expression 'narrow' [bornierte] twice in this passage. Firstly, he is addressing capitalism (wealth in its narrow bourgeois form). Secondly, he refers to the non-capitalist 'old world', which is only satisfying from a narrow point of view (the point of view of closed shape, closed form and given limitations). The idea of wealth beyond its capitalist form (or value) stands in opposition to these two forms of narrowness. Marx is thus counterposing narrow social forms (capitalist and non-capitalist) with an idea of wealth as an open, multilateral and 'totally elaborated' social form. This idea of wealth contains the emancipatory intent of his social critique.

The contradiction between wealth and value involves four aspects of the concept of wealth that have been posited by capitalism but are also blocked by it: 1) the full development of human mastery over internal and external nature; 2) the absolute elaboration of human creative dispositions; 3$)$ the reproduction, not of a human determinate character, but of a totality of determinations; and 4) the absolute movement of becoming, and the possibility not to remain in a limited form that has come to be. These four qualitative determinations of

1 All quotes from German-language texts are my own translations. 
wealth become understandable under a categorical analysis, showing that capitalism produces an abstract form of social mediation, based on value and independent from previous qualitative forms of production and consumption.

Now, these four dimensions of social wealth (which I will summarize as the concept of a 'multilateral social form') are confronted with both capitalist and non-capitalist forms of one-sidedness. Non-capitalist societies appear as unilateral as long as they are mediated by qualitatively determined social forms, such as relations of direct domination and tradition. These social relations are unilateral as long as they embed people under the very determinateness [Bestimmtheit] of their particular and traditional forms of existence. Capitalism, on the other hand, is also a form of social unilaterality, though it is based not on particular traditions or personal authority, but on the tautological movement of self-reproducing value. The mediating character of labor grounds modernity's basic features, as modern forms of social relations are based on quasi-objective, anonymous compulsions. Marx states that only in capitalism is the goal of the reproduction of value imposed over social life. By contrast, in non-capitalist forms, the satisfaction of needs stands as the goal of production. "So the old view, in which man-whatever the narrow national, religious or political determination-always appears as the aim of production, seems to be very exalted against the modern world" (Marx 1983, p. 411). Capitalism replaces the unilaterality of previous national, religious or political determinations [Bestimmungen] with a new form of one-sidedness, based on production for the sake of production itself.

The opposition between capitalist and non-capitalist forms of one-sidedness can be analyzed categorically departing from the features of value and capitalist labor. With the transition to capitalism, according to Postone, the very nature of social mediation changes. This transition is associated with the passage from overt social relations to a set of quasi-objective relations, which appear not as social, but as objective and abstract. Social mediation in capitalism is structured as a set of impersonal dynamics, alien to individuals and fundamentally selfmoving. In non-capitalist societies, Postone claims, labor as such does not mediate society, but is embedded in activities otherwise determined:

This is quite different from social formations in which commodity production and exchange do not predominate, where the social distribution of labor and its products is effected by a wide variety of customs, traditional ties, overt relations of power, or, conceivably, conscious decisions. (Postone 1993, p. 149)

In non-capitalist societies, labor does not mediate social relations, but is dependent on other aspects of practice such as tradition, customs and even con- 
scious decisions. Capitalist society, on the other, is articulated by forms of distorted praxis in which the very activities of human beings appear as something alien to them, governed by objective and impersonal laws:

Central to Marx's analysis is the argument that the relations that characterize capitalist society are very different from the forms of overt social relations -such as kinship relations or relations of personal or direct domination-that characterize noncapitalist [sic.] societies. The latter sorts of relations are not only manifestly social, they are qualitatively particular; no single, abstract, homogeneous sort of relation underlies every aspect of social life. (Postone 1993, p. 153)

The transition to capitalism is also the transition to modern society, in which overt social relations recede. Bonds of personal dependence sanctioned by tradition lose their mediating nature. Now, labor itself (and its expression in its products, commodities and value) comes to mediate society. This transformation gives rise to a new, specifically capitalist form of social domination, which is based not on bonds of direct dependence, but on a universal system of social interdependence which assumes a set of reified and fetishistic forms:

The hallmark of modern, or capitalist society is that, because the social relations that essentially characterize this society are constituted by labor, they exist only in objectified form. (Postone 1993, p. 154)

When Marx speaks about 'total alienation [Entfremdung]' and 'the sacrifice of the end in itself [Selbstzwecks] under a completely external end' with the rise of capitalism, he is addressing these new forms of social domination. He provides a double-sided account of capitalism. Since it is based on a quasi-objective, abstract form of social mediation, capitalism confronts individuals as a set of independent social powers that it cannot control or change by political decision or otherwise. Yet on the other hand, capitalism confronts other forms of social reproduction that are based on direct relations of personal domination with 'qualitatively particular' (Postone 1993, p. 153) forms of mediation.

Social wealth, as opposed to both the extant unilateral forms of capitalism and non-capitalist societies, aims towards the development of a multilateral form of social mediation and production, no longer based on determinate traditions or personal authority, nor on the abstract mediation of value and labor. Social wealth should be regarded as an emancipatory potential of modernity-a possibility that has been created by the immanent dynamic of capitalism, but that could only be realized through the overcoming of value and labor as social mediators. 


\section{Social wealth and the emancipatory potentials of modernity}

The idea of social wealth not only involves the increasing accumulation of goods, but is grounded in the dynamics of social interaction. This is related to a process of universalization of human interaction by which the capacities and needs of individuals come to be socially produced in a historically unprecedented manner. This movement of universalization is made possible by the dynamic of capitalism. Yet, its full realization would involve moving beyond capitalism and the objective compulsions of value and labor.

With the transition from overt social relations to the quasi-objective and impersonal constrictions of labor and value, significant transformations take place in the sphere of production. As Postone states, forms of social mediation and concrete forms of production are intertwined. "Marx analyzes the basic social relations of capitalism, its form of wealth, and its material form of production, as interrelated" (Postone 1993, p. 27). What fundamentally changes with the capitalist form of production is that the creation of goods tends to rest ever less on the direct expenditure of labor and becomes increasingly dependent on the productive use of socially generated knowledge. This new form of production, while it makes labor more one-sided and winding for the worker, also creates the conditions for a different form of wealth (capable of transcending value), which could be grounded in universal social interaction rather than direct labor. The idea of social wealth, qualitatively understood, aims at this transformation of the very process of production.

Capitalism entails a dual transformation of the relation between individuals, production and society as a whole. On the one hand, with the capitalist form of mediation, the modern individual as an independent person appears, as previous forms of direct domination recede. On the other hand, production for selfconsumption or immediate subsistence tends to disappear. Capitalism makes people both more independent (from direct forms of authority) and more dependent (on the universal process of social exchange). This dual process is carried out in an alienated form through the dynamic of capital, which people cannot control. The overcoming of capitalism would involve the collective appropriation of the productive forces created by capital itself.

The individual emerges socially under capitalist social relations. "The more we go back in history, the more the individual (and also the productive individual) appears as dependent [unselbständig] and belonging to a greater whole" (Marx 1983, p. 34). The modern, independent individual is a historical result: "Man (...) is not only a social animal, but an animal that can individualize itself 
only in society" (Marx 1983, p. 35). In non-capitalist social forms, the creation of consumable goods or use values is the direct goal of production. In that context, the individual appropriates his conditions of labor under the framework of the community. Marx speaks of the "existence of the individual as a member of a community-his nature-like existence [naturwüchsiges Dasein] as member of a tribe, etc." (Marx 1983, p. 409). In non-capitalist forms, there is a more direct link between the individual and the community, which mediates between him and his conditions of existence or property: "[s]o ownership means belonging to a tribe (community)" (Marx 1983, p. 415). The origin of capitalism involves the dissolution of the communal forms in which labor stands as the owner of its conditions. "The behavior of labor towards capital, or towards its objective conditions of labor as capital, presupposes a historical process that dissolves the different forms in which the worker is an owner, or in which the owner works” (Marx 1983, p. 420). The dissolution [auflösung] of communal forms gives rise to 'free' labor -free of both communal direct bonds and of property, confronted by capital as an alien power. The result of this historical process of dissolution is the appearance of a mass of free and dispossessed workers, "whose only property is their labor power and the possibility to exchange it against existent values” (Marx 1983, p. 420).

Capitalism displaces a communitarian nexus and also produces a new form of social mediation developed along with the social division of labor. Individuals, now independent from personal or communal ties, become completely dependent on one another through exchange. Under capitalism, "my product is only a product as long as it is so for others; so it is a superseded individual [aufgehobnes einzelne], a universal [allgemeine]" (Marx 1983, p. 143). Productive units now work for a universal system of exchange. At the same time, new needs appear that are socially created by the global process of interaction itself.

When production for exchange (for the creation of value instead of use values) is thoroughly established, it also comes to modify the material process of production itself. This becomes evident with the growth of fixed capital and machinery. Mechanized production entails the radical subordination of labor under capital, but also lays the foundations for the possible overcoming of capitalism. "Inserted into the production process of capital, the means of labor pass through different metamorphoses, whose culmination is the machine or, rather, an automatic system of machinery (...), set in motion by an automaton” (Marx 1983, p. 610). This 'automaton' is created by the powers of socially developed knowledge. The worker appears here as the 'conscious organ' of the automated machine, so he is no longer a mere manual worker. Yet, this does not immediately turn his work into something less unilateral or unpleasant: he has been turned into an appendix of the machine as an embodiment of capital. "The develop- 
ment of the means of labor into machinery is not fortuitous for capital, but is the historical transformation of the traditionally established means of labor, converted into means adequate to capitalism" (Marx 1983, p. 612).

Traditional tools are subordinated to the worker in the labor process, since they merely transmit 'the activity of the worker to the object' (Marx 1983, p. 610). The means of production are formally turned into fixed capital when they confront labor as an alien property. Nevertheless, there are no material differences between the traditional instrument as fixed capital and as a property of the worker. With the development of machinery, capital transcends formal domination and comes to materially govern production. "The production process has ceased to be a work process in the sense of being controlled by work as its dominant unit" (Marx 1983, p. 611). Machines, far from being mere instruments of human labor, turn labor into an instrument of their own self-generated movement. Capital, in this way, comes to transform material production, positing itself as its subject.

This process, nevertheless, also creates the possibility of social wealth as outlined in the previous section. The development of machinery leads to a radical 'socialization' of production based on the general introduction of universally formed productive forces into the process of production. While independent villages or communities may have local, traditional, particular and determinate forms of production, production for exchange tends to homogenize, through competition, productive techniques and methods. Now the 'social and universal' powers of science and technology become the dominant productive forces, while direct labor loses importance. "The immediate work is both quantitatively reduced to a lesser proportion and qualitatively reduced to an essential, but subaltern moment against the general scientific labor [allgemeine wissenschaftliche Arbeit]" (Marx 1983, p. 614, emphasis added).

With the development of machinery and automation: a) knowledge, science and technology, and not direct labor, come to be the determining factors of production; and b) the knowledge that grabs hold of production is inherently social and possesses a universal character, since it is the result of the global development of production for exchange and is not tied to particular traditions or customs. The idea of a total elaboration of human abilities and needs not only opposes unilateral forms of existence (whether determinate, based on direct domination, or abstract, based on labor)-it also entails that every productive unit now works with socially general means and resources, which have been created through a universal process of human interaction involving knowledge and science.

The social powers of knowledge and science, developed under the alienated conditions of capitalism, could be the basis of a post-capitalist society. This so- 
ciety would no longer be based on labor time as the measure of value and would therefore be free of the quasi-objective and impersonal compulsions this brings about. Yet it would not recede to previous forms of personal domination. Instead, it would be 'free', structured neither by direct forms of domination nor by abstract coercions. This possibility is also created by the development of wealth under capitalism, which could dialectically go beyond value.

The social individual that arises with social wealth has multilateral needs and capacities, since they have been produced by social knowledge in a universal process of social interaction. This process, while it has been made possible under capitalism, points beyond it. "Real wealth is the developed productive power of all individuals. It is then no longer labor, but disposable time that is the measure of wealth" (Marx 1983, p. 622, emphasis added). The basis for this shift is that the driving productive factor is no longer direct labor, but the socially created power of science and technology, embedded in machines. In this way, wealth can be understood categorically: it is not just determined by the growing amount of goods produced, but also by the social characteristics of their production and consumption. Social wealth is related to an individual whose needs and capacities are universal, since they have been produced by social interaction, knowledge and exchange.

\section{Conclusion: globalization and philosophy of universal history}

Johannes Rohbeck, who is otherwise critical of Postone, has pointed out that Marx attempted to 'free philosophy of history from metaphysical assumptions' (Rohbeck 2006, p. 83). Marx grounds world history in the global development of 'economic exchange'; in a 'historical process that today is called globalization' (Rohbeck 2006, p. 85). Marx could be regarded as 'one of the first theorists of globalization' (Rohbeck 2006, p. 86). World history is not, in this reading, an ahistorical and intemporal given in which capitalism can simply be located. On the contrary, world history is determined under very specific historical conditions-namely, those of the world market and the global production for exchange.

Rohbeck's considerations may allow us to understand how a critical theory of globalization could be developed from the foundations of the categorical critique. This critique is itself concerned with modernity as such. It understands that social domination is embedded in the fundamental structures of the social mediation of capitalist modernity. Globalization, from this perspective, involves 
the universalization of an impersonal and quasi-objective, alienated form of mediation.

Yet, capitalist modernity is nevertheless a form of domination as much as it is creative and generative. It posits, along with its alienated movement, historical possibilities that could transcend it. These possibilities are contained in social wealth and in the social individual. While capitalist technologies are not emancipatory in themselves, they involve emancipatory possibilities because they render direct human labor less and less relevant in production.

Social wealth and the possibility of the social individual arise from a process of the globalization of knowledge, human capacities and needs. Under capitalism, productive units tend to lose their independence. This means that the goal of production and consumption involves the whole world. Productive forces become social: they are no longer specific to a single productive unit, nor based on a particular custom or traditional method.

Finally, capitalist production also transforms human needs. The creation of new needs by capitalism certainly involves forms of compulsive consumerism with irrational sides, but their flipside is the fact that individuals are confronted with the possibility of appropriating the historical results of cultures other than their own. So production for value also brings about emancipatory potentials, related to the idea of a multilateral form of human interaction and production, based not on particular traditions nor on value and labor, but on universal knowledge and the general growth-both quantitative and qualitative-of socially created, universal wealth.

\section{Bibliography}

Kellner, Douglas (2002): “Theorizing Globalization”. In: Sociological Theory, Vol. 20, No. 2, pp. $285-305$.

Marx, Karl (1983): Grundrisse der Kritik der politischen Ökonomie. In: Marx-Engels Werke, Vol. 42, Berlin: Dietz Verlag.

Postone, Moishe (1993): Time, Labor and Social Domination. A Reinterpretation of Marx's

Critical Theory. Cambridge: Cambridge University Press.

Postone, Moishe (2009): History and heteronomy. Critical Essays. Tokyo: UTCP.

Rohbeck, Johannes (2006): Marx. Leipzig: Reclam. 
